\title{
The Analysis of Teacher's Pedagogical Competence in the Implementation of Character Education in High School (SMA) Koto Tangah District
}

\author{
$\operatorname{Irsyad}^{1, *}$, Rifma $^{1}$, Anisah $^{1}$ \\ ${ }^{1}$ Department of Educational Administration, Faculty of Education, Universitas Negeri Padang, Padang, Indonesia \\ *Email, irsyad1122@gmail.com
}

\begin{abstract}
This study aims to determine the teacher's pedagogical competence of high school in implementing character education on senior high school teachers of Koto Tangah District, Padang City, especially in aspects of understanding students' characteristics, understanding learning theories and learning principles that educate and aspects of ability in developing curriculum. This research was conducted through a qualitative descriptive approach. The instruments used were questionnaires and observation sheets, interview guidelines, audio / video recording devices. The crosscheck of data by data triangulation techniques. Then the data are analyzed with the following steps: 1) data collection; 2) data reduction; 3) data display, and 4) verification and conclusion. The results of this research that the teachers of the Koto Tangah Senior High School District already had abilities in pedagogical competencies with an average of 3.23 in the able category. Teacher pedagogical competence in aspects of understanding the characteristics of students with an average score of 3.24 with the category of quite capable; pedagogical competence in the aspect of ability to master learning theory and principles of learning that educate with an average of 3.14 in the underprivileged category; and teacher pedagogical competence in aspects of developing curriculum with an average of 3.65 in the able category. Thus it can be said that the pedagogical competence of Koto Tangah District Senior High School teachers can be said to be capable.
\end{abstract}

Keywords: teacher pedagogical competence, character education

\section{INTRODUCTION}

A pleasant and warm learning atmosphere to achieve satisfying goals and learning outcomes can be addressed with relevant strategies, methods and media. Students' ability to understand the material presented by the teacher is influenced by the ability and competence of teachers in managing learning. One of the competencies that must be possessed by a teacher is pedagogical competence, which includes, among others, understanding student characteristics, mastering learning theory and learning principles, and the ability to develop curriculum. Teachers who have good pedagogical competence are assumed to be able to create an interesting and enjoyable learning atmosphere, so that the objectives of each learning as desired can be achieved. With the creation and implementation of a pleasant learning atmosphere it is also hoped that the implementation of character education in schools will also be realized. Thus, it is hoped that the desired learning outcomes are not only achieving desired learning goals but are also able to form intellectual, emotional and spiritual intelligent students. In general, it can be said that with the application of appropriate pedagogical competencies, the goal of creating graduates who have good character will also be achieved.

The picture shows that the teacher's task is actually very heavy and strategic. Therefore, to be able to carry out these tasks properly, teachers must meet existing requirements. The process of education and learning does not merely educate by transferring knowledge, technology, and skills (transfer of knowledge), but also develops the attitudes, personalities, and character building of their students. In the process, the mastery of knowledge to be taught, how to convey, the attitudes, personality, and behavior of teachers has a great influence on the development of their students

The task of the teacher as a learning designer, namely designing learning in such a way as to create a systematic learning process so that the teaching and learning process can be realized effectively and efficiently in achieving educational goals. For this reason, a teacher must have good pedagogical competence. In preparing the learning design, the teacher must know to know and fulfill all learning needs so that the learning process and inculcation of character values in students can take place effectively and efficiently.

Whether or not character education is implemented in a school is very much determined by a teacher. Teachers are people who interact directly with their students and 
teachers who play an important role in the cultivation of character education for their students. For this reason, a teacher must possess competent competence so that school goals and national education goals can be achieved.

However, the phenomenon that is seen in the field is that there are teachers who do not have and apply good pedagogical competence. For example, teachers still do not understand how to make lesson plans in implementing character education in schools. The teacher prefers to look at existing learning tools without paying close attention to the advantages and disadvantages of these devices, whether it is suitable for improving the character education of students. Therefore, this study tries to look more deeply at how mastery of teachers towards pedagogical competence in implementing character education in the Senior High School of Koto Tangah District, Padang City.

\section{THEORETICAL FRAMEWORK}

In regulation No. 14 of 2005 concerning Teachers and Lecturers. In part of 10 it is stated that there are four competencies that must be possessed by teachers, namely pedagogical, personality, social, and professional competencies. The four competencies must be mastered by the teacher well, because in carrying out their duties the teacher does not deal with inanimate objects, but faces a person who is growing and developing, a person who has diverse abilities, traits, attitudes, and characters that requires different treatment. With his competence, the teacher will know the situation so he will try to provide different treatments tailored to the needs of each student. Pedagogical competence is an ability related to the management of teaching and learning. In relation to the teaching and learning process Ali[1] states as follows: For the teaching and learning process to run effectively, each teacher must have four basic abilities in teaching, namely: (1) the ability to understand learning theories; (2) the ability to develop teaching systems; (3) the ability to carry out effective teaching and learning processes; (4) the ability to assess learning outcomes, as feedback from the teaching and learning activities it does.

Viewed from the side of pedagogical competence, the real task of teachers in the learning process is not only limited to conveying knowledge to students, but teachers must also function as a facilitator, motivator, and inspiration for their students. Teachers must facilitate their students so they can learn in a pleasant, energetic, and not depressed atmosphere. Such learning atmosphere will cause children to have freedom and courage to think because they feel there is appreciation from all parties for their abilities. The teacher must also be able to function as a motivator for their students so they learn vigorously. In addition, in the learning process, the teacher must also be able to function as an inspiration (inspirator). This means that in every learning activity carried out, the teacher must be able to provide inspiration for students, so that learning activities can generate a variety of ideas, ideas, and new ideas that are good, and original (original). For that the teacher must be able to create a comfortable and pleasant learning atmosphere.

Thus it can be said that pedagogical competence is the ability to understand students in depth and the organization that educates. In the National Education Standards, the Explanation (Article 28 paragraph (3) points a, n.d.) states that pedagogical competence is the ability possessed by teachers in the management of teaching and learning which includes student understanding, curriculum development, assessment, and actualizing students' potential.

Kunandar[2] argues that the ability of teachers related to pedagogical competence includes several parts namely understanding the characteristics of students, designing curriculum/lesson plans, including understanding the foundation of education and learning principles, implementing learning that educates, designing and implementing evaluation of learning, and develop students to actualize their various potentials.

So pedagogical competence is the ability and skills possessed by a teacher in understanding the character of students, developing curriculum, the ability to carry out learning, design assessments, actualize students.

Sagala[3] also suggests that teachers who are able to use pedagogical competencies, will be able to create an atmosphere of learning that is able to develop initiatives. Teacher's competence will encourage students to be more critical, creative, collaborative, and communicative in order to increase emotional/social maturity, so that students are productive, and ready to face changes and participate in the change process. According to Agung[4], the teacher as an educator is one of the factors that determines the success of any educational endeavor, especially in improving the quality of human resources resulting from educational endeavors, and this endeavor always boils down to the teacher factor. Thus it can be said that how exist the role of the teacher in the education process.

Based on the above considerations, a fundamental picture can be obtained about the importance of teacher pedagogical competence, because pedagogical competence is a basic competency that must be possessed by teachers and is developed based on the analysis of the tasks that must be done by the teacher and reflected in the teaching and learning process to achieve optimal learning outcomes.

Based on the above considerations, a fundamental picture can be obtained about the importance of teacher pedagogical competence, because pedagogical competence is a basic competency that must be possessed by teachers and is developed based on the analysis of the tasks that must be done by the teacher and reflected in the teaching and learning process to achieve optimal learning outcomes.

Law of the Republic of Indonesia No. 20 of 2003 concerning the National Education System has affirmed that national education functions to improve the ability of human resources and shape the character and morals of a dignified national civilization to educate the life of the nation, to develop the ability of students to become people 
of faith and piety to God Almighty, noble, healthy, knowledgeable, capable, creative, independent, and become a democratic and responsible citizen. To realize all this, teachers should understand well and be able to apply the pedagogical competence appropriately.

By mastering and applying this pedagogic competency, indirectly the cultivation of character values in students, both during the learning process takes place in the classroom and outside the classroom, will also be implemented well.

The inculcation of character values in students must be planned by the teacher as best as possible, starting from the preparation of learning tools, when the learning process and after the learning process in class is complete. That is, it must be done by teachers continuously.

In strengthening character education, teachers can integrate character values in the learning tools that will be used as in the classroom and able to manage the class well. Whereas the principal can design the school culture that characterizes and excels the school. The character values that should be understood and implemented by the teacher while carrying out their duties are: nationalism, integrity, independence, mutual cooperation, religious. In its application, the teacher will relate it to the pedagogical competence.

\section{METHOD}

This research is a qualitative descriptive study. The population taken was all high school teachers in Koto Tangah sub-district, totalling 157 people. The sample was carried out using the Proportional Stratified Random Sampling technique. The number of samples is 62 respondents. The instruments used in data collection were questionnaires and interview guidelines. Data is processed by finding averages and supplementing them with qualitative data obtained through limited interviews with several teachers and students.

\section{RESULTS AND DISCUSSION}

Based on the results of research on "Pedagogical Competency Analysis of Senior High School Teachers in Koto Tangah District" the following conclusions can be drawn:

- Aspects of understanding the characteristics of students are in the category of being able with an average score of 3.23.

- Aspects of understanding learning theory and principles of learning that educate are in the category of underprivileged with an average score of 3.14.

- The ability aspect in developing curriculum is in the category of able with an average score of 3.65.

This proves that the pedagogical competency analysis of Koto Tangah District Senior High School teachers is quite capable, but it still needs to be improved in the future.

\subsection{Pedagogical Competence}

According to Law Number 20 of 2003 and according to Law No 16 of 2007 Pedagogical competence is one of the competencies that must be possessed, mastered and applied by teachers in their learning activities. Among the pedagogical sub competencies are 1) the ability to understand the characteristics of students, 2) the ability to master learning theories and learning principles, and 3) the ability to develop the curriculum that is taught.

First, the ability to understand students. According to Rifma[5] understanding of students and their characteristics can affect the behavior and forms of teacher services to students. Therefore, a more specific understanding is needed about students, so that the education services provided by teachers are more in line with individual differences in students.

So the understanding of students, namely the teacher must know and understand students well, understand the stages of development that have been achieved, their abilities, advantages and disadvantages, obstacles encountered and the dominant factors that influence it.

Second, the ability to master the theory of learning and the principles of learning that educate. Mastering the theories and principles of learning is a form of teacher understanding related to how to present effective learning through educative interactions based on appropriate learning theories and principles.

According to the Malang Methodical Didactic Team in Janawi[6] asserted that the principle that was considered necessary to be mastered by educators, namely the principle of attention, the principle of activity, the principle of apperception, the principle of demonstration, the principle of repetition, the principle of correlation, the principle of concentration, the principle of individualization, the principle of socialization, and evaluation principle.

Third, the ability to develop curriculum. According to Sidi in Kunandar[2], argues that the national education curriculum must be developed based on several indicators, namely the education curriculum must be flexible, simple, and can accommodate a variety of possible changes in the future as a result of technological developments and community demands, the curriculum must be the main guidelines for student learning activities, curriculum development should be carried out simultaneously with the development of teaching materials (books and student worksheets) and media or learning tools, the education curriculum should be a unity and continuity with the education units and levels above it.

The curriculum is a description of the teaching and learning process that is designed in an educational institution. In the curriculum, it is explained what materials will be taught to students, the systematic learning process, the learning methods, the media that will be used in learning, and all matters related to learning needs.

So, teacher competence in curriculum/syllabus development is very important because curriculum/ syllabus is the foundation in the implementation of the educational process in schools, a good curriculum design 
will create a learning process and graduates with quality and character.

\subsection{Character Build}

In the Strengthening Character Education training module for teachers there are five main values for strengthening character education, namely:

First Religious, this character value is a value associated with God Almighty. Religious values include peace, tolerance, respect for religious differences and beliefs, firm stand, self-confidence, cooperation between religions and beliefs, antibuly and violence, friendship, sincerity, not forcing the will, loving the environment, protecting the small and marginalized.

Second Nationalist, The value of nationalist character is a way of thinking, behaving, and acting that shows loyalty, care, and high respect for language, physical environment, social, cultural, economic, and political nation, placing the interests of the nation and state above self-interest and his group.

Third Mandiri, the value of independent character is an attitude where we do not depend on others as long as we are able both in terms of energy, thought, and time to achieve all the goals we want to achieve. Being independent does not mean not needing others, but being independent is trying to do all activities without the help of others while we are able.

Fourth Mutual Assistance, Character values of mutual cooperation is an act of mutual assistance to help between all members of the group or organization. Mutual cooperation is an act of mutual cooperation in a group to alleviate all the burdens of all members in the group. Character values of mutual cooperation that can be embedded in learning activities in the classroom are like cleaning the classroom and school environment.

Fifth Integrity, the value of integrity character is an attitude that we do in which every speech and attitude that is done is always honest, so that it can be trusted by others, this attitude is applied in the teaching and learning process that is like not cheating during an exam, always honest in carrying out class picket, and so forth.

So there are five character values that must be instilled in students in the learning process, namely, religious, nationalist, independent, mutual cooperation, and integrality.

Associated with sub competencies of teacher pedagogical competencies, specifically sub competencies 1) Understanding learners in depth; 2) Designing learning, including understanding the educational foundation for the benefit of learning; 3) Implementing learning in implementing character values can already be said that the teacher is able to apply them. It's just that, in the aspect of understanding the theory and principles of learning still need to be improved. Because aside from the average answers from the teachers being in the sufficient category, the students stated that there were still some teachers who had not yet implemented the learning process as demanded in pedagogical competence. During the learning process there are still some teachers who use conventional learning methods and techniques, the class is not alive, the learning atmosphere tends to be monotonous, there are even a small number of teachers who only assign students to take notes and learning material that should be discussed.

In the current educational environment, it has actually made it easy for teachers to present learning models that are interesting, challenging and fun. Of course this needs serious attention and improvement, by means of an approach taken by the school to provide adequate insight into what and how to implement these competencies in learning. In addition, it is also possible to include teachers in education and training carried out by parties outside the school, such as the Educational Quality Assurance Institute or from the West Sumatra Province Education Office

\section{CONCLUSIONS AND SUGGESTIONS}

Pedagogic competence is an ability that must be possessed by teachers starting from understanding students ranging from talent, motivation, interest, physical, students' ability to absorb learning, and social learners, the ability of teachers to develop curriculum, which should be a simple curriculum, flexible, accommodate a variety of possible changes in the future as a result of technological developments and community demands, and the ability to master the theory of learning and learning principles.

Learning is an activity designed by teachers to achieve national education goals effectively and efficiently. With the implementation of learning, teachers are expected to be able to apply character education, because the goal of national education is to educate the nation's life and make people who have good character. For this reason, in planning learning, teachers must include the values of character education in their learning design. Starting from planning learning, implementing learning, and assessing learning outcomes

\section{REFERENCES}

[1] M. Ali, Guru dalam Proses Belajar Mengajar. Bandung: Sinar Baru Algensindo, 2004.

[2] F. N. M, "Kompetensi Guru dalam Peningkatan Prestasi Belajar pada SMP Negeri Dalam Kota Banda Aceh," J. Adm. Pendidik. Pascasarj. Unsyiah, vol. 3, no. 1, pp. 45-67, 2015.

[3] S. Sagala, Kemampuan Profesional Guru dan Tenaga Kependidikan: Pemberdayaan Guru, Tenaga Kependidikan, dan Masyarakat dalam Manajemen Sekolah. Bandung: Alfabeta, 2011.

[4] I. Agung, "Peran Fasilitator Guru dalam Penguatan Pendidikan Karakter (PPK)," Perspekt. Ilmu Pendidik., vol. 31, no. 2, pp. 106-119, 2017. 
[5] Y. E. Violita and Rifma, "Layanan Prima Tenaga

Administrasi Sekolah di Sekolah Menengah Kejuruan

(SMK) Muhammadiyah I Padang," J. Bahana Manaj.

Pendidik., vol. 8, no. 3, pp. 54-60, 2019.

[6] Wulandari, Rifma, Irsyad, and Anisa, "Analisis Kompetensi Pedagogil Guru dalam Pengimplementasian Pendidikan Karakter di Sekolah Menengah Atas (SMA) Kecamatan Koto Tangah," J. Bahana Manaj. Pendidik., vol. 8, no. 3, p. 55, 2019. 